УДК: 378.016:[80+33+002.1]

DOI: $10.15330 /$ esu. $1.38-44$
Марія Якубовська,

доцент, Українська академія друкарства

(м. Львів, Україна)

Mariia Yakubovska,

Associate Professor,

Ukrainian Academy of Printing (Lviv, Ukraine)

mmamariat92@gmail.com

Вікторія Будзінська,

військовий психолог, фахівець 3 міжнародних

відносин та інформаційної безпеки суспільства

Академії Сухопутних військ ЗСУ

(м. Львів, Україна)

Viktoriia Budzinska,

military psychologist, expert in International Relations and Information Security of society

National Ground Forces Academy of Armed Forces of (Lviv, Ukraine)

mmamariat92@gmail.com

\title{
Я.ДАШКЕВИЧ ТА І.КАЛИНЕЦЬ: ПАРАДИГМА ДУХОВНОГО ДІАЛОГУ ЯК АРХЕТИП ФОРМУВАННЯ АКСІОЛОГГЧНИХ ЗАСАД КУЛЬТУРОЛОГГЧНОЇ КОМПЕТЕНТНОСТІ СУЧАСНИХ СТУДЕНТІВ
}

\section{YAROSLAV DASHKEVYCH AND IRYNA KALYNETS: THE PARADIGM OF SPIRITUAL DIALOGUE AS AN ARCHETYPE OF FORMING OF AXIOLOGICAL FOUNDATIONS OF MODERN STUDENTS' CULTURAL COMPETENCE}

Дослідження пов'язане із пошуком інновачійних педагогічних засобів системного формування аксіологічних засад у парадигмі становлення особистості сучасного студента як важливий компонент культурологічної компетентності. У статті подано наукове обтрунтувания вивчения дискурсу творчого діалогу Ірини Калинечь та Ярослава Даикевича та їх роль у формуванні загальнокультурної компетентності як парадигми професійного становлення сучасного фахівчя. Досліджуються особливості иляхів впроваджения культурологічної підготовки у навчально-виховний прочес закладів вищої освіти. Частково обгрунтовано варіативні технології забезпечення основ культурологічної підготовки майбутніх професіоналів-фахівчів.

На прикладі вивчення творчого діалогу Ірини Калинечь та Ярослава Даикевича розглядасться проблема аксіологічної складової у системі професійної освіти студентів. Досліджуються конщептуальні аксіологічні засади творчого діалогу Ірини Калинечь та Ярослава Дашкевича на новітньому рівні розвитку інновачійних педагогічних засад, ио дозволяе по-новому осмислити проблему співвіднесення розвитку людської індивідуальності і світу. Розглядасться роль аксіологічних засад, які сприяють формуванню якісно нового фахівчя; становленню взасморозуміния між людськими індивідуальностями.

Досліджується стратегія виховання молоді в дусі збереження, примноження культурологічного спадку, пізнання й усвідомления й залучения до загальнолюдських иінностей, ио вимагає від педагогів високого рівня ерудичії, загальної культури, здатності до самоосвіти, самовихования та педагогічного хисту, фахової компетентності особистості, яка є носієм і транслятором вартостей духовної культури. Дані концептуальні принциити дозволяють витворювати відповідний навчально-виховний культурологічний феномен сучасної освіти. Досліджуються аксіологічні засади культурології як фактор забезпечення сочіальної стійкості системи відносин людини і суспільства, людини й іниих людей, що ефективно виливас на формувания свідомості, самосвідомості, сочіальнопрофесійних якостей особистості. 
Ключові слова: системний, компетентнісний, особистісно-діяльнісний, культурологічний та аксіологічний методи, культурологічна компетентність, професійна ocвima.

The research is related to the search for innovative pedagogical means of systematic formation of axiological foundations in the paradigm of becoming a modern student as an important component of cultural competence. The article substantiates the scientific substantiation of the study of the discourse of creative dialogue between Irina Kalinets and Yaroslav Dashkevich and their role in the formation of cultural competence as a paradigm for professional development of a modern specialist. The peculiarities of the ways of introducing cultural preparation in the educational process of higher education institutions are investigated. Variational technologies of providing the basics of cultural training of future professionals are partially substantiated.

The problem of axiological component in the system of students' professional education is considered on the example of studying the creative dialogue between Irina Kalinets and Yaroslav Dashkevich. The conceptual axiological foundations of the creative dialogue of Irina Kalinets and Yaroslav Dashkevich at the newest level of development of innovative pedagogical foundations are investigated, which makes it possible to rethink the problem of correlation of the development of human personality and the world. The role of axiological principles that contribute to the formation of a qualitatively new specialist is considered; the development of mutual understanding between human individuals.

The strategy of education of young people in the spirit of preservation, augmentation of cultural heritage, cognition and awareness and attraction to common human values, which requires from teachers of high level of erudition, general culture, ability to self-education, selfeducation and pedagogical hist, vocational competence, professional competence the values of spiritual culture. These conceptual principles allow to produce the relevant educational and cultural phenomenon of modern education. The axiological principles of cultural studies as a factor of ensuring the social stability of the system of relations between man and society, man and other people are studied, which effectively influences the formation of consciousness, selfconsciousness, social and professional qualities of personality.

Key words: systemic, competence, personality-activity, cultural and axiological methods, cultural competence, professional education.

Актуальність дослідження. Культурологічна підготовка студентів технічних університетів як соціально-педагогічний принцип розвитку системи освіти стає наріжним каменем формування сучасного фахівця високого якісного рівня. Тільки гармонійне поєднання професійних знань із сформованим духовним світом майбутнього фахівця можуть дати основу для формування архетипу культурологічної компетентності сучасних студентів ВНЗ. У процесі формування парадигми цієї системи сучасні педагогічні інноваційні системи вищої професійної освіти потребують яскравих прикладів творчої духовної взаємодії видатних особистостей нашої доби. Фахівець нової епохи повинен усвідомлювати відповідальність, яку бере за творення нових духовно-інтелектуальних шляхів у парадигмі новітньої доби. Дослідження системи аксіологічних цінностей сучасної парадигми інноваційної особистісно зорієнтованої освіти вимагає новітнього осмислення культурологічної спадщини минулого.

Новизна дослідження. Розглядається аксіологічна складова у системі художньої культурологічної спадщини творчого духовного діалогу Ірини Калинець та Ярослава Дашкевича як засіб у творенні інноваційної моделі сучасної професійної особистісно зорієнтованої освіти. 
Мета дослідження - розглянути систему аксіологічних цінностей творчого духовного діалогу Ірини Калинець та Ярослава Дашкевича як концептуальний засіб у творенні парадигми сучасної інноваційної особистісно зорієнтованої освіти.

Методи дослідження. Для вирішення окреслених завдань та досягнення мети основними методами дослідження були загальнонаукові: аналіз, синтез, порівняння та узагальнення. Також використовувався семантичний, син енергетичний, культурологічний та герменевтичний методи. Зазначений методологічний підхід дозволив проаналізувати системне творення інформаційної безпеки суспільства як складової загальної гуманітарної парадигми сучасної інноваційної освіти.

Проблема формування різних граней культури знайшла широке відображення у зарубіжній та вітчизняній науковій думці. Досліджується філософія культури (П. Гуревич, В. Межуєв, С. Франк та ін.), соціологія культури (П. Струве та ін.), педагогіка культури (С. Гессен, І. Зязюн, В.Кремень та ін.); культурологія як філософський феномен (Б. Кононенко та ін.). На нинішній час існує цілий ряд досліджень даної наукової проблеми, серед яких виділяємо наступні напрямки: формування культурологічної компетентності як інноваційної парадигми сучасності досліджують у своїх працях В. Андрущенко, О. Асмолов, Г. Балл, І. Бех, Т. Бутківська, О. Вишневський, І.Зязюн, В.Кремінь, Н. Ничкало, Ю. Пелех, В. Сластьонін, Е. Соколов та ін. Питання виокремлення професійної культури фахівців різного профілю в структурі їхньої загальної культури вже привернули увагу чималої кількості дослідників, серед яких О.Андрущенко, І.Бех, Л. Байкіна, Л. Гребєнкіна, Л. Зеліско, I. Ісаєв, Н.Ничкало, О.Сухомлинська, І. Сенча та ін. На нинішній час постала проблема визначення конкретних шляхів реалізації формування культурологічного світогляду студентів технічних університетів, майбутніх професіоналів-фахівців.

Ці проблеми є складовою частиною культурологічної підготовки студентів технічних університетів. Сучасному етапові розвитку вітчизняної історико-педагогічної думки притаманна динамічна інтеграція знань, перевага надається комплексному, всебічному аналізові об'єктивних історичних явищ, домінантою наукових досліджень стає посилення зв'язків між науками та науковими явищами.

Як показує досвід, приклади із життя видатних діячів сучасності стають для студентів основою для наслідування, теорія їхньої навчальної діяльності набуває якісної осмисленості. Лише такий процес здатен сформувати таланти для динамічної конкурентоспроможності країни.

У цій інноваційній педагогічній системі важливим $\epsilon$ не проста емпірична розповідь про видатних людей свого часу, а несподіваний ракурс подачі у тому чи іншому контексті. Проблема "людина і суспільство", “людина і громадська чи політична діяльність" в умовах сучасного духовного життя логічніше трансформується як “індивідуальність - індивідуальність як проблема творчої взаємодії'.

Культурологічна компетентність із чітко вираженою системою аксіологічних цінностей дозволяє сформувати міцну мотиваційну основу професійної діяльності. Власне культурологія більше, ніж будь-яка інша сфера глибокого внутрішнього світу людини, забезпечує постійну соціальну стійкість у системі відносин людини і суспільства, людини і сфери професійної діяльності, людини й інших людей. Така система також ефективно впливає на формування моральної свідомості, самосвідомості, багатогранних професійних якостей студента технічного університету. 
Архетип творчого діалогу Ярослава Дашкевича та Ірини Калинець - яскраве підтвердження тих прогресивних тенденцій сучасного духовного розвитку суспільства. Кінець XX - початок XXI століття характерний інтенсивною появою у сучасному культурологічному процесі творів мемуарно-есеїстичної літератури. Як правило, ці твори мають високий художній зміст і користуються популярністю серед масового читача.

Люди поміж рядками таких творів шукають відповіді на злободенні явища дійсності, оскільки виникає гостра потреба об'єктивного переосмислення суспільнополітичних подій з позиції досягнень сучасного історико-філософського вчення, коли домінуюча роль у цих процесах має належати людській індивідуальності і здатності особистості до перетворення явищ об'єктивної дійсності.

Сучасна освіта тримає руку на пульсі формуванні загальнолюдських цінностей, котрі є рушійними силами суспільного прогресу. Як стверджує більшість сучасних вчених, модернізація освіти повинна іти шляхом створення діалогічної моделі сучасного суспільства. Культура - це суспільний процес формування самосвідомості особистості, в основі якого лежить духовність. Згідно 3 дослідженнями Н. Розова, формування системи цінностей складається із таких структурних частин: формування відповідальності за загальнолюдські цінності, глибинне усвідомлення цінностей самовизначення особистості, формування компетентності, а також особистісна самоактуалізація.

Модернізація освіти спонукає звернути серйозну увагу на гуманітарнокультурологічні підходи у підготовці до життя молоді, на розвиток молодих людей як суб'єктів не лише професійної, а й гуманітарної культури суспільства.

Сучасний студент потребує емоційного зацікавлення у пізнанні цих явищ. Більше того, інноваційне використання окремих предметів гуманітарного циклу буде корисним не лише для гуманітарного виховання студента, a i для активізації мисленнєвої діяльності, пошуків внутрішніх ресурсів для ефективного навчання, а згодом і для продуктивної праці.

Творчий діалог Ярослава Дашкевича та Ірини Калинець носить багатовимірний характер: від творчої наукової співпраці до активних пошуків становлення і розвитку українського суспільства. Спільні зацікавлення історією Ірини Калинець та Ярослава Дашкевича носили глибинний характер: минуле для них було не простим набором фактів, а триванням живого духу нації, народу; реальним продовженням великої франкової справи, де “дух тіло зве до бою”.

Спільність життєвих переконань і долі була вирішальним імперативом у постійному творчому діалогові Ярослава Дашкевича та Ірини Калинець. У талановитому романі Ірини Калинець “Вбивство тисячолітньої давності” виведено образ Ярослава Дашкевича як людини вдумливої, толерантної із великої силою людяності. "Ярослав Дашкевич (Ярослав Іван Ананія де Корибут) (1926-2010), український історик, громадський діяч, почесний громадянин м. Львова (1997). Син знаменитих батьків - Романа-Миколи де Корибут Дашкевича та Олени Степанів, він і сам став яскравою особистістю львівського культурного середовища. Ярослав Дашкевич отримав освіту у Львові в нелегкі роки - 1944-1949, навчався у Львівському медичному інституті, філологічному факультеті Львівського університету; працював у Львівській бібліотеці АН УРСР. 1949 р. Я. Дашкевича було арештовано як сина буржуазної націоналістки Олени Степанів за звинуваченням у переховуванні та розповсюдженні контрреволюційної літератури. Р. Дашкевича засудили до 10 років таборів, він вийшов на свободу після смерті 
Сталіна 3 того часу до 1990 р. чергувалися періоди недовгого працевлаштування та повного безробіття, зазнавав утисків та був звинувачений у некомпетентності. Тим не менш за цей час Ярослав Дашкевич захистив дисертацію, займався науковою роботою і став визначним спеціалістом у вірменознавстві, історії, археографії. 1972 р. Я. Дашкевич оженився із Людмилою Шереметєвою (1946-2005), українською правозахисницею, журналісткою, родом з Кіровограда. Навчаючись в Одеському інституті, Л. Шереметєва увійшла в дисидентське середовище, була активною розповсюджувачкою самвидаву, брала участь у дисидентському русі. Від 1967 року вона мешкала у Львові, в 1990-1997 рр. працювала літературним редактором газети "Ратуша" [5].

Ірина Калинець належить до покоління шістдесятників - того покоління, яке винесло на своїх плечах найважливіше: відчайдушний супротив тоталітарній системі в умовах найжкорстокішого тиску. "Бо мало нас, малесенька щопта..." - так писав про це покоління Василь Стус, друг i побратим по боротьбі Ірини Калинець. Переслідування, тюрми, арешти, заслання - все це у біографії нескореної Ірини Калинець вимережкано як фатальність необхідності.

“Весняна шістдесятницька відлига - пора, в яку Ірина Калинець студіювала славістику у Львівському державному університеті імені Івана Франка (1959-1964). Після закінчення університету працювала у кількох львівських школах. В умовах незалежної України стала начальником Управління освіти Львівської області (19901992). За іi ініціативами розпочали активну перебудову навчального процесу в школах, зміну програм, працю над створенням гімназій, ліцеїв, зокрема Львівського державного ліцею імені героїв Крут, коледжів, авторських і приватних шкіл, відродження "Пласту". Інститут підвищення кваліфікації педагогічних працівників реорганізовано в Науково-методичний інститут освіти, а це сприяло удосконаленню навчальних шкільних програм та написанню новітніх підручників. 1987 р. стала співредактором самвидавчого журналу “Евшан-зілля". 1990-1994 pp. - депутат ВР України першого скликання, де очолювала підкомісію з питань шкільництва. 3 2002 р. - доцент, а 32003 р. - професор кафедри української літератури імені академіка Михайла Возняка Львівського національного університету імені Івана Франка. 1998 р. за громадську діяльність іiі визнано "Героїнею світу" (США, Ротчестер), 2000 р. нагороджено орденом Княгині Ольги III ступеня, у 2006 році орденом Княгині Ольги II ступеня (Україна)" [5].

Підпільна видавнича діяльність, видання часопису „Свшан-зілля”, гуртування навколо родини Калинців науково-мистецької еліти - це наступний період діяльності письменниці. Саме у цьому середовищі визрівав бунт проти комуністичної системи як об'єктивної необхідності. В'ячеслав Чорновіл був лідером цього гурту нескорених, але душею залишалася Ірина Калинець. Вона була першою, хто приніс у приміщення Верховної Ради України першого демократичного скликання жовтоблакитний прапор - наш національний символ. Із молодечим завзяттям Ірина почала реформувати національну освіту.

Багатогранний досвід творчого діалогу видатних особистостей нашої сучасності $€$ парадигмою формування культурологічної компетентності студентів ВНЗ. Допомагає розробити науково-методичні рекомендації щодо впровадження у навчальний процес моделі і методики формування культурологічної підготовки на засадах сталого розвитку особистості майбутніх фахівців. Допомагає грунтовно формувати сукупність педагогічних умов (реалізація діяльнісного підходу до формування культурологічної підготовки майбутніх фахівців; використання 
проблемних, частково пошукових та дослідницьких методів навчання; забезпечення дієвості наявних мотивів, посилення інтеграції теоретичних знань майбутніх економістів); створювати компоненти (мотиваційний, знаннєвий, гностичний, поведінковий), критерії (мотиваційна готовність, сформованість особистісної позиції, рівень культурологічної підготовки; сформованість культурологічної підготовки i показники рівнів іiі сформованості (активно-діяльнісний, продуктивний, реконструктивний, репродуктивний, пасивно-споживацький).

Багатогранність і багатовимірність творчого діалогу Ярослава Дашкевича та Ірини Калинець - річ незаперечна. Науковець, дослідник 3 величезною науковою інтуїцією і просто феноменальними знаннями Ірина Калинець була не просто другом i однодумцем Ярослава Дашкевича, a i логічним продовженням його поглядів. Їі наукові праці скеровані у майбутнє. На нинішній час ще не кожен може осмислити істинно високе значення іiі досліджень. Непоборне прагнення до волі, почуття високої патріотичної відповідальності, громадсько-політичної i християнської гідності, активної життєвої позищії стало могутніми факторами, які поєднували у єдине духовне ціле творчі дослідження Ірини Калинець та Ярослава Дашкевича.

До книги "Епоха гунів та їі передісторія" передмову написав видатний історик Ярослав Дашкевич, який високо оцінив працю дослідниці, над якою вона трудилася майже двадцять літ. Ярослав Дашкевич зазначив, що впродовж десятиріч, які минули від "Походження Атіли" Івана Франка до серії досліджень видатного сходознавця Омеляна Пріцака, опублікованих німецькою та англійською мовами, українська література про гунів обмежується побіжними згадками в загальних курсах історії, а "праця Ірини Калинець заповнює прогалини української наукової думки у цій ділянці”. “Ігор Калинець колись висловився, що Ірині Калинець “судилося спізнати радість творення і блаженство натхнення" [5]. Сумнівів у цьому й справді нема. Ї̈̈ зацікавлення унікальною пам'яткою слов'янства - не банальне бажання “вписати” своє ім'я до “сонму” літературознавців-академістів, а швидше глибинна і внутрішня потреба сучасної спадкоємиці далеких предків долучитися до тих, хто шукає відповідей на запитання, які ще й досі таїть у собі “Слово...”, себто, як називав його Михайло Грушевський, цей древній “збір загадок, котрі все ще можна рішити певно і твердо". Ірина Калинець спробувала по-своєму прояснити деякі “темні місця" цієї унікальної пам'ятки, а також запропонувала нову версію походу Ігоря на половців" [5].

Проза Ірини Калинець $є$ підтвердженням ідейних устремлінь авторки. Детективність сюжету роману "Вбивство тисячолітньої давності" переплітається 3 науковою глибиною першовідкриттів та шляхетністю оповіді. Переплітаються часові плошини, розкриваються болячки сучасності, висвітлюються недосліджені сторінки історії, ведеться полеміка з приводу наболілих питань... У 1997 р. побачила світ об'ємна книга, до якої увійшли іiі детективний роман Ірини Калинець "Вбивство тисячолітньої давності”, новели і повість Ігоря Калинця “Молімось зорям дальнім”, яка знайшла відгук серед інтелектуальної еліти України.

Поетична творчість Ірини Калинець - ще однин архетип творчого світу, який $\epsilon$ логічним продовженням ідейного діалогу двох величних постатей ХХ століття Ірини Калинець та Ярослава Дашкевича.

...Осипається тіло в пісок дороги.

Слово безмовне в пісок осипається.

Свою дорогу самотності

Перейти за міраж [9, с. 31] 
Цей вірш звучить як підсумок певного етапу: бо немає кінця досконалості, немає кінця дорозі буття. Але ось ця досконалість - наслідок важких потуг духу стає причиною самотності: індивідуальне "я" переходить у вимір обраних вищою суттю. Найвища істина - любов, найвище благо - прощати. Це узагальнюючесинтетичне бачення світу лежить в основі архетипу поетики творчості Ярослава Дашкевича та Ірини Калинець.

Висновки та перспективи подальших досліджень. У системі сучасної інноваційної освіти формування аксіологічних цінностей займає важливе місце. Гадаємо, що цей характерний феномен невтомної людської діяльності потребує не лише наукового осмислення, a i мусить бути використаний у педагогічній інноваційній практиці.

Світ швидко змінюється, і необхідно бути достатньо мобільними, щоб не тільки перебудовувати свою економіку, а й мати достатню підготовку, аби працювати при нинішніх світових тенденціях. Таким чином можна досягти успіху в створенні й отриманні прибутку в нових секторах до того, як їх освоять інші. Тому система вищої освіти - важливий чинник успіху розвитку країни. На відміну від попередніх десятиліть, коли для потужного зростання були важливі природні й виробничі ресурси, зараз найголовніше - людський капітал. В освіті та науці важливий ефект критичної маси: чим більше талантів, тим вища продуктивність кожного з них і тим конкурентоспроможнішою є країна. Яскравим підтвердженням цього є творчий діалог Ярослава Дашкевича та Ірини Калинець.

\section{Література}

1. Оноре де Бальзак, Думки про мистецтво.- К.: Мистецтво, 1981.-253 с.

2. Бичко А.К. та ін. Теорія та історія світової та вітчизняної культури: Курс лекцій. - К.: Либідь, 1992. - 392 c.

3. Гончаренко С. Український педагогічний словник. - Київ: Либідь, 1997. - 376 с.

4. Гюго В. Мистецтво і народ. - Київ: Мистецтво, 1985.- 336 с.

5. Дашкевич Ярослав. "Учи неможними устами сказати правду..." http://incognita.day.kiev.ua/uchi-nelozhnimi-ustami-skazati-pravdu.html

6. Зеліско Л. Культура як складова професійної підготовки особистості // Педагогіка i психологія професійної освіти. - 2009. - №4. - С. 51-63

7. Зязюн I. Освітній простір культури в умовах сучасних інформаційних технологій // Рідна школа. - 2006. - № 5. - С. 3 - 6 .

8. Калинець І. Шлюб із полином.- Львів: Місіонер, 1998.- 226 с.

\section{References}

1. Onore de Balzak, Dumky pro mystetstvo.- K.: Mystetstvo, 1981.- $253 \mathrm{~s}$.

2. Bychko A.K. ta in. Teoriia ta istoriia svitovoi ta vitchyznianoi kultury: Kurs lektsii. - K.: Lybid, 1992. - $392 \mathrm{~s}$.

3. Honcharenko S. Ukrainskyi pedahohichnyi slovnyk. - Kyiv: Lybid, 1997. - 376 s.

4. Hiuho V. Mystetstvo i narod. - Kyiv: Mystetstvo, 1985.- $336 \mathrm{~s}$.

5. Dashkevych Yaroslav. "Uchy nemozhnymy ustamy skazaty pravdu..." http://incognita.day.kiev.ua/uchi-nelozhnimi-ustami-skazati-pravdu.html

6. Zelisko L. Kultura yak skladova profesiinoi pidhotovky osobystosti // Pedahohika i psykholohiia profesiinoi osvity. - 2009. - №4. - S. 51-63

7. Ziaziun I. Osvitnii prostir kultury $\mathrm{v}$ umovakh suchasnykh informatsiinykh tekhnolohii // Ridna shkola. - 2006. - № 5. - S. $3-6$.

8. Kalynets I. Shliub iz polynom .- Lviv: Misioner, 1998.- $226 \mathrm{~s}$.

Одержано статтю: 11.09 .2019

Прийнято до друку: 1.10 .2019 